\title{
The economic effects of the fair tax: analysis of results of a dynamic CGE model of the US economy
}

\author{
Keshab Bhattarai ${ }^{1}$ - Jonathan Haughton ${ }^{2}$. \\ David G. Tuerck ${ }^{2}$
}

Published online: 28 May 2016

(C) The Author(s) 2016. This article is published with open access at Springerlink.com

\begin{abstract}
By replacing the current income tax with a national sales tax, the FairTax proposal would end the double taxation of saving inherent in the existing tax code and, by doing so, raise output, employment, investment and capital stock relative to the benchmark economy. While these positive effects would be felt almost immediately, the FairTax is very much an investment in the future. Its full benefits would be realized only after the economy achieved a new "steady state," some 20-25 years into implementation. Only by that point, will the effects on growth have been fully absorbed into the economy and the wellbeing of most households across most income groups improved. The policy choice, then, is between the status quo, and a new policy that would inflict some short-run pain as the price of a permanently expanded economy.
\end{abstract}

Keywords Dynamic CGE - Tax reform · Growth · Distribution · US economy

JEL Classification $\mathrm{C} 68 \cdot \mathrm{E} 24 \cdot \mathrm{D} 63 \cdot \mathrm{O} 15$

\section{Introduction}

The U.S. federal tax code has undergone major changes since the last important attempt at tax simplification in 1986. In the intervening years, Congress has enacted legislation to raise and then lower income tax rates, reduce the tax rates on capital gains and dividends, increase deductions for IRA contributions, create both Individual Retirement Accounts and Medical Savings Accounts, increase the Earned Income Tax Credit for the poor, and make other

Keshab Bhattarai

K.R.Bhattarai@hull.ac.uk; http://www.hull.ac.uk/php/ecskrb/

1 The Business School, University of Hull, Cottingham Road, Hull HU6 7SH, UK

2 Department of Economics and Beacon Hill Institute at Suffolk University, 8 Ashburton Place, Boston, MA 02108, USA 
changes. The result is over 70,000 pages of tax code, rules and rulings that continues to swell by a thousand pages annually (see U.S. Congress. Congressional Budget Office (1992), U.S. Congress. Joint Committee on Taxation (1995), U.S. Government Accountability Office (2005)). ${ }^{1}$ Additionally, the existing tax code continues to discriminate against saving, thus imposing a drag on capital formation, production and economic growth.

Taxation remains at the heart of the policy debate. In the Economic Report of the President 2014 (CEA 2014), Barack Obama starts his "opportunity agenda" with the statement that "Number one is more new jobs," and goes on to say that companies should be encouraged to hire "by closing wasteful tax loopholes and lowering tax rates for businesses that create jobs here at home" (p.2).

Thoroughgoing tax reform plans have been proposed form time to time. The President's Commission on Federal Tax Reform made recommendations for widespread changes in its 2005 report. $^{2}$ Hall and Rabushka proposed a flat tax in 1983 an idea that was subsequently promoted by presidential candidate Steve Forbes (2005), and has been embraced in one form or another by several Eastern European countries.

In this paper we analyze the effects of the FairTax proposal, a cousin of the flat tax proposals. The archetype of radical tax reform, the FairTax would repeal all federal direct taxes (on personal and corporate income, capital gains, payroll, estates, and gifts) and replace them with a national retail consumption tax (the "FairTax") levied at a taxinclusive rate that, to ensure revenue neutrality, would be set at $23 \%$ (Bachman et al. 2006). An interesting and important feature of the FairTax proposal is that it would include a universal "demogrant" that would provide a payment to every individual large enough to offset any tax payments on spending up to the poverty line.

Boortz and Linder (2005), who advocate adoption of the FairTax - Linder filed H.R. 25, the FairTax Act, in 2005 - claim that in the first year after the FairTax becomes law the economy would grow by $10.5 \%$, exports by $26 \%$, and capital spending by more than $70 \%$. Jokisch and Kotlikoff (2005) predict that output would be $10.6 \%$ higher and the capital stock $83.3 \%$ higher in 2100 , and the real wage would rise by $13 \%$, rather than decline by $5 \%$ (as it would under current law) by the end of the century; national income would be $6.25 \%$ higher and the capital stock $41.4 \%$ higher. Arduin et al. (2005) find that the FairTax would increase total economic output by $11.3 \% 10$ years after implementation: investment would be $41 \%$ higher and employment $9 \%$ higher.

Our study is designed to evaluate these extravagant claims, using a custom-built computable dynamic general equilibrium model of the U.S. economy that allows us to arrive at our own estimates of the economic effects of the FairTax proposal. We sketch out the model in section 2 , discuss the relevant parameters in section 3 , present the results in section 4 , and draw the main conclusions in the final section.

\section{Overview of the BHI model}

Sweeping tax changes such as the FairTax proposal have general equilibrium effects throughout the economy, changing prices, incomes, employment, savings, interest rates

\footnotetext{
${ }^{1}$ http://www.cch.com/TaxLawPileUp.pdf

${ }^{2}$ The final report of the President's Advisory Panel on Federal Tax Reform available at http://www. taxreformpanel.gov/final-report.
} 
and exchange rates. The most appropriate tool for quantifying these effects is a computable general equilibrium (CGE) model. Since their beginnings in the 1970s, CGE models have been used to address tax issues, and are routinely used by government agencies such as the U.S. Treasury, the Congressional Budget Office, and International Trade Commission for policy analysis. A very clear early exposition is provided in Shoven and Whalley $(1984,1992)$.

We have constructed a large, 15,000-variable, disaggregated dynamic national CGE model of the United States economy. The essence of our model is shown in Fig. 1, which is heavily inspired by Berck et al. (1996), and where arrows represent flows of money (for instance, households buying goods and services) and goods (for instance, households supplying their labor to firms).

Households own the factors of production - land and capital - and are assumed to maximize their lifetime "utility", which they derive from consumption (paid for out of after-tax income) and leisure, both now and in the future. Households must decide how much to work, and how much to save. They are also forward-looking, so that if they see a tax change in the future, they may react by changing their decisions even now. By eliminating the personal income tax, corporate income tax, payroll taxes and estate taxes at the federal level, the FairTax would raise lifetime utility; the introduction of a federal sales tax would work in the other direction.

The other major actor is the government, which imposes taxes and uses the revenue to spend on goods and services, as well as to make transfer payments to households. We have calibrated the model so that the effects of the FairTax will be revenue-neutral.

Implicitly, there is also a production sector where producers/firms buy inputs (labor, capital, and intermediate goods that are produced by other firms), and transform them into outputs. Producers are assumed to maximize profits and are likely to change their decisions about how much to buy or produce depending on the (after-tax) prices they face for inputs and outputs. The endowment of capital depreciates over time, and is reconstituted through investment, which is undertaken in anticipation of future profits. The implementation of the FairTax raises the levels of investment and capital stock by

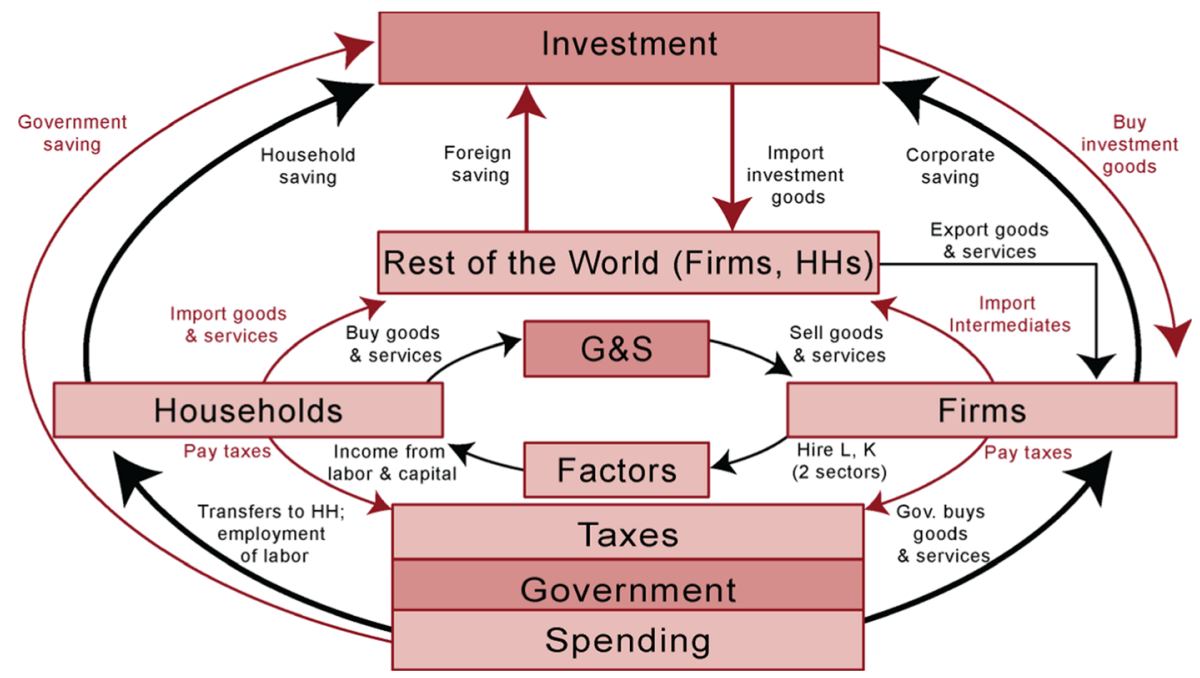

Fig. 1 Circular flow in a CGE model 
removing the sector-specific distortions caused by the existing tax system in the benchmark economy.

To complete the model there is a rest-of-the world sector that provides goods (U.S. imports) and purchases U.S. exports. Trade is represented by the standard Armington assumption, which uses a constant-elasticity-of-transformation function to determine the allocation between domestic sales and exports. The benchmark reference part of the economy is represented by a steady-state growth rate for quantities of all goods and services.

Complex as it may seem, Fig. 1 is still relatively simple, because it lumps all households into one group, and all firms into another. To provide further detail it is necessary to create sectors; our model has 68 economic sectors. Each sector is an aggregate that groups together segments of the economy. We separate households into seven income classes and firms into 27 industrial sectors. In addition, we distinguish between 19 types of taxes and funds (nine at the federal level and 10 at the state and local level) and 11 categories of government spending. To complete the model, there are two factor sectors (labor, capital), an investment sector, and a sector that represents the rest of the world. The choice of sectors was dictated by the availability of suitably disaggregated data (for households and firms), and the purposes of the model. The underlying data are gathered into a 68 by 68 social accounting matrix (SAM), which includes an input-output table as one of its components.

\subsection{The formal specification of the model}

Space does not permit an exhaustive presentation of our model, so here we set out just the key components.

Infinitely-lived households allocate lifetime income to maximize the present value of lifetime utility $\left(L U^{h}\right)$, which itself is a time-discounted CES aggregation of a composite consumption good $\left(C_{t}^{h}\right)$ and leisure $\left(L_{t}^{h}\right)$, with an elasticity of substitution between consumption and leisure given by $\sigma_{u}^{h}$ (as in Bhattarai 2001, 2007). Note that the composite consumption good is in turn a Cobb-Douglas aggregation of 27 domestically-produced, and 27 imported, goods and services.

The representative household faces a wealth constraint where the present value of consumption and leisure cannot exceed the present value of its full disposable income $\left(J_{t}^{h}\right)$, which gives lifetime wealth $\left(W^{h}\right)$. Under current tax rules, this implies

$$
\sum_{t=0}^{\infty} \mu(t)\left(P_{t}\left(1+t^{v c}\right) C_{t}^{h}+w_{t}^{h}\left(1-t_{l}\right) L_{t}^{h}\right)=W^{h}
$$

where $\mu(t)$ is a discount factor, $P_{t}$ is the price of consumption, $C_{t}^{h}$ is composite consumption, $t^{\nu c}$ is the sales tax on consumption, $t_{l}$ represents taxes on labor income, and $w_{t}^{h}$ is the wage rate. With the FairTax, this constraint becomes

$$
\sum_{t=0}^{\infty} \mu(t)\left(P_{t}\left(1+t^{F}\right) C_{t}^{h}+w_{t}^{h} L_{t}^{h}+D_{t}\right)=W^{h}
$$

where $t^{F}$ represents the FairTax rate, and $D_{t}$ is the demogrant that represents a cash payment to every person. 
The structure of production is summarized in Fig. 2. Starting at the bottom, and for each of the 27 production sectors, producers combine labor (which comes from seven different categories of households) and capital (using a CES production function, with elasticity of substitution $\sigma_{v}$ ) to create value-added, which is in turn combined with intermediate inputs - assumed to be used in fixed ("Leontief") proportions - to generate gross output. This output may be exported or sold domestically, modelled with a constant elasticity of transformation (CET) export function between the U.S. markets and all other economies. The domestic supply is augmented by imports, where we use a constant elasticity of substitution (CES) function between domestically supplied goods and imports.

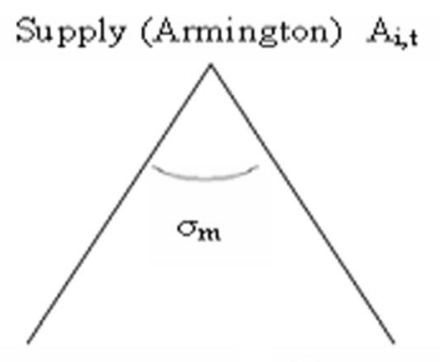

Imports

Domestic Sales

Exports

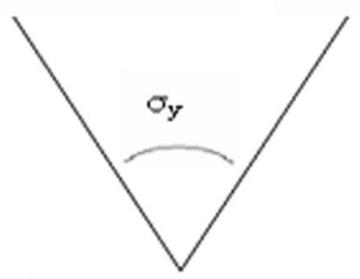

Gross Output $Y_{i, t}$

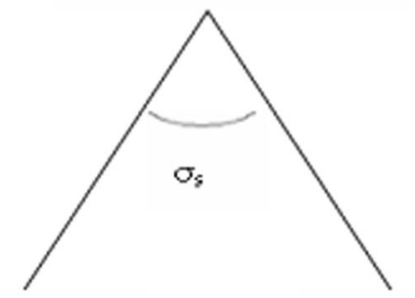

St .

Value Added

Intermediate Inputs

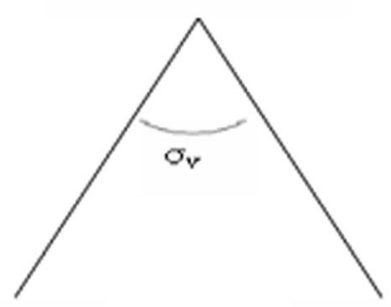

Labor

Capital

Fig. 2 Nested structure of production and trade in the FairTax model for sector i 
The underlying growth rate in the BHI CGE model is determined by the growth rate of labor and capital. Labor supply, which is equivalent to the household labor endowment less the demand for leisure, rises in line with population. The capital stock $(K)$ for any sector in any period is given by the capital stock in the previous period (after depreciation) plus net investment $(I)$. On a balanced-growth path, where all prices are constant and all real economic variables grow at a constant rate, the capital stock must grow at a rate fast enough to sustain growth. This condition can be expressed as:

$$
I_{i, T}=K_{i, T}\left(g_{i}+\delta_{i}\right)
$$

where the subscript $T$ denotes the terminal period of the model, $\delta_{i}$ is the depreciation rate, and $g_{i}$ is the growth rate for sector $i$ and is assumed uniform across sectors for the benchmark economy.

Although the time horizon of households and firms is infinite, in practice the model must be computed for a finite number of years. Our model is calibrated using data for 2004 and stretches out for 27 years (i.e. through 2031). To ensure that households do not eat into the capital stock prior to the (necessarily arbitrary) end point, a "transversality" condition is needed, characterizing the steady state that is assumed to reign after the end of the time period under consideration. We assume, following Ramsey (1928), that the economy returns to the steady state growth rate of $3 \%$ at the end of the period.

The model also requires a number of identities. After-tax income is either consumed or spent on savings. Net consumption is defined as gross consumption spending less any consumption tax. The flow of savings is defined as the difference between after-tax income and gross spending on consumption, and gross investment equals national saving plus foreign direct investment.

A zero trade balance is a property of a Walrasian general equilibrium model; export or import prices adjust until the demand equals supply in international markets. However, foreign direct investment (FDI) plays an important role in the U.S. economy, as exports and imports are not automatically balanced by price adjustments. Therefore our Walrasian model is modified here to incorporate capital inflows so that the FDI flows in whenever imports exceed exports. Thus

$$
F D I_{t}=\sum_{i} P M_{i, t} M_{i, t}-\sum_{i} P E_{i, t} E_{i, t}
$$

where for period $t, F D I_{t}$ is the amount of net capital inflows into the U.S. economy, $\sum_{i} P M_{i, t} M_{i, t}$ is the volume of imports and $\sum_{i} P E_{i, t} E_{i, t}$ is the volume of exports.

\subsection{Calibration to steady state}

The model is truly "dynamic" in that it is optimized over time, and is calibrated using data for 2004. The model is programmed in GAMS (General Algebraic Modeling System), a specialized program that is widely used for solving CGE models (Brooke et al. 1998). The core of the model is programmed in the mathematical programming for system of general equilibrium (MPSGE) code, which was written by Thomas Rutherford (1995) to facilitate the development of market-clearing dynamic CGE models; see also Lau et al. (2002). 
The model is calibrated to ensure that the baseline grows along a balanced growth path. In the benchmark equilibrium, all reference quantities grow at the rate of labor force growth, and reference prices are discounted on the basis of the benchmark rate of return. The balance between investment and earnings from capital is restored here by adjustment in the growth rate $g_{i}$ that responds to changes in the marginal productivity of capital associated with changes in investment. Readjustments of the capital stock and investment continue until this growth rate and the benchmark interest rates become equal.

If the growth rate in sector $i$ is larger than the benchmark interest rate, then more investment will be drawn to that sector. The capital stock in that sector rises as more investment takes place, leading to diminishing returns on capital. Eventually the declining marginal productivity of capital retards growth in that sector.

To solve the model, we allow for a time horizon sufficient to approximate the balanced-growth path for the economy. Currently the model uses a 26 years horizon, which can be increased if the model economy does not converge to the steady state.

\section{Behavioural elasticities of substitution in consumption and production}

Our CGE model simulates the effects of tax changes. The structure of the model depends not only on the magnitudes in the social accounting matrix, but also on the behavioural parameters, which reflect how consumers and producers react to changes in prices. These parameters are mainly in the form of elasticities of substitution, but also include depreciation and discount rates, and an assumed steady state growth rate. The parameters we use are set out in Table 1, and are comparable to those found in the existing literature; including Tuerck et al. (2006), Bhattarai and Whalley (1999), Killingsworth (1983), Kotlikoff (1993, 1998), Kydland and Prescott (1982), Ogaki and Reinhart (1998a, b), Piggott and Whalley (1985), and Reinert and Roland-Holst (1992).

Table 1 Basic parameters of the FairTax model

$\begin{array}{ll}\text { Steady state growth rate for sectors }(g) & 0.03 \\ \text { Net interest rate in non-distorted economy }(r \text { or } \varrho) & 0.03 \\ \text { Sector specific depreciation rates }\left(\delta_{\mathrm{i}}\right) & 0.02-0.12 \\ \text { Elasticity of substitution in domestic returns and capital flows, } \sigma_{\mathrm{k}} & 1.0 \\ \text { Elasticity of substitution for composite investment, } \sigma & 1.0 \\ \text { Elasticity of transformation between U.S. domestic supplies and } & 2.0 \\ \quad \text { exports to the Rest of the World (ROW), } \sigma_{\varepsilon} \text { (can be sector-specific) } & 1.5 \\ \text { Elasticity of substitution between U.S. domestic products and imports } & 1.0 \\ \quad \text { from the Rest of the World (ROW), } \sigma_{\mathrm{m}} & 0.2 \\ \text { Inter-temporal elasticity of substitution, } \sigma_{\mathrm{Lu}} & 1.0 \\ \text { Intra-temporal elasticity of substitution between leisure and composite goods, } \sigma_{\mathrm{u}} & 2.0 \\ \text { Elasticity of substitution in consumption goods across sectors, } \sigma_{\mathrm{C}} & (1+g)^{t-1} \\ \text { Elasticity of substitution between capital and labor, } \sigma_{\mathrm{v}} & 1 /(1+r)^{t-1} \\ \text { Reference quantity index of output, capital and labor for each sector, } Q_{r f} & \\ \text { Reference index of price of output, capital and labor for each sector, } P_{r f} & \end{array}$


A few further comments are in order. The intertemporal elasticity of substitution $\left(\sigma_{L u}\right)$ measures the responsiveness of the composition of a household's current and future demand for the composite consumption good to relative changes in the rate of interest, and is a crucial determinant of household savings. There is little consensus in the literature about a reasonable value for this elasticity: Ogaki and Reinhart (1998a, b) estimate it to be between zero and 0.1 in the case of durable goods; Hall and Rabushka (1983) finds it to be very small, even negative, while Hansen and Singleton (1983) note the lack of precision in the estimates of $\sigma_{L u}$. Auerbach and Kotlikoff (1987) assume it to be about 0.25; Kydland and Prescott (1982) assume it to be 1.0, which is also the value we use.

The intratemporal elasticity of substitution between consumption and leisure $\left(\sigma_{u}\right)$ determines how consumers' labor supply responds to changes in real wages. Indirect evidence on this elasticity is derived from various estimates of labor supply elasticities that are available in the literature (Killingsworth 1983). Here we adopt a value of 0.2 for this substitution elasticity. Further discussion on how to derive numerical values of substitution elasticities from labor supply elasticities is provided in earlier studies on tax incidence analysis (Bhattarai and Whalley 1999).

The intratemporal elasticity of substitution among consumption goods $\left(\sigma_{C}\right)$ captures the degree of substitutability among goods and services in private final consumption. A higher value implies more variation in consumption choices when the relative prices of goods and services change. Consistent with Piggott and Whalley (1985), we specify a value of 1.0 for this parameter.

The Armington elasticity of transformation $\left(\sigma_{e}\right)$ determines the sale of domesticallyproduced goods between the home and foreign markets in response to relative prices between these two markets. The Armington substitution elasticity $\left(\sigma_{m}\right)$ determines how the domestic and import prices affect the composition of demand for home and foreign goods. Higher values of these elasticities mean a greater impact of the foreign exchange rate in domestic markets. Reinert and Roland-Holst (1992) report estimates of substitution elasticities for 163 U.S. manufacturing industries and find these elasticities to be between 0.14 and 3.49. Piggott and Whalley (1985) suggest central tendency values of these elasticities to be around 1.25.

Early estimates of the elasticity of substitution between capital and labor $\left(\sigma_{v}\right)$ may be found in Arrow et al. (1961). They estimated constant elasticities of substitution for U.S. manufacturing industries using a pooled cross country data set of observations on output per man hour and wage rates for a number of countries; we use a value of 2.0.

\section{Results}

We formulate and solve the model using the GAMS/MPSGE software (Rutherford 1995), with the PATH solver in GAMS (Brooke et al. (1998)). The model is first calibrated. The data from the SAM, and the assumed elasticities, are used to identify the parameters of the model's equations. These equations are then solved. If they generate the same numbers as the SAM, then the model has been calibrated successfully. The benchmark model is first solved on the assumption that the current Federal tax system persists into the foreseeable future. This provides a benchmark against which to judge the effects of major tax changes. 
Table 2 Summary of effects of the FairTax (relative to benchmark, \% change), 2007-2031

\begin{tabular}{llllllllll}
\hline $\begin{array}{l}\text { Year } \\
\text { Period }\end{array}$ & $\begin{array}{l}2007 \\
1\end{array}$ & $\begin{array}{l}2008 \\
2\end{array}$ & $\begin{array}{l}2009 \\
3\end{array}$ & $\begin{array}{l}2010 \\
4\end{array}$ & $\begin{array}{l}2011 \\
5\end{array}$ & $\begin{array}{l}2016 \\
10\end{array}$ & $\begin{array}{l}2021 \\
15\end{array}$ & $\begin{array}{l}2026 \\
20\end{array}$ & $\begin{array}{l}2031 \\
25\end{array}$ \\
\hline Real GDP & 3.9 & 5.1 & 5.7 & 6.3 & 6.8 & 8.1 & 8.8 & 9.4 & 10.1 \\
Investment & 69.5 & 81.0 & 82.7 & 84.1 & 85.2 & 86.1 & 86.4 & 89.0 & 94.7 \\
Capital stock & -0.5 & 2.1 & 4.5 & 6.6 & 8.4 & 14.3 & 17.6 & 19.9 & 21.9 \\
Employment & 4.9 & 4.9 & 4.6 & 4.3 & 4.0 & 3.0 & 2.4 & 2.2 & 2.1 \\
Consumption & -1.4 & -1.4 & -0.8 & -0.3 & 0.2 & 2.0 & 3.0 & 3.5 & 3.6 \\
\hline
\end{tabular}

We then assume that in 2007, the major Federal direct taxes (personal and corporate income taxes, payroll taxes, and gift and estate duties) are replaced by the FairTax, at a rate that is revenue-neutral in 2007 , and turns out to be $23 \%$ on a tax-inclusive basis. The same FairTax rate is applied every year thereafter.
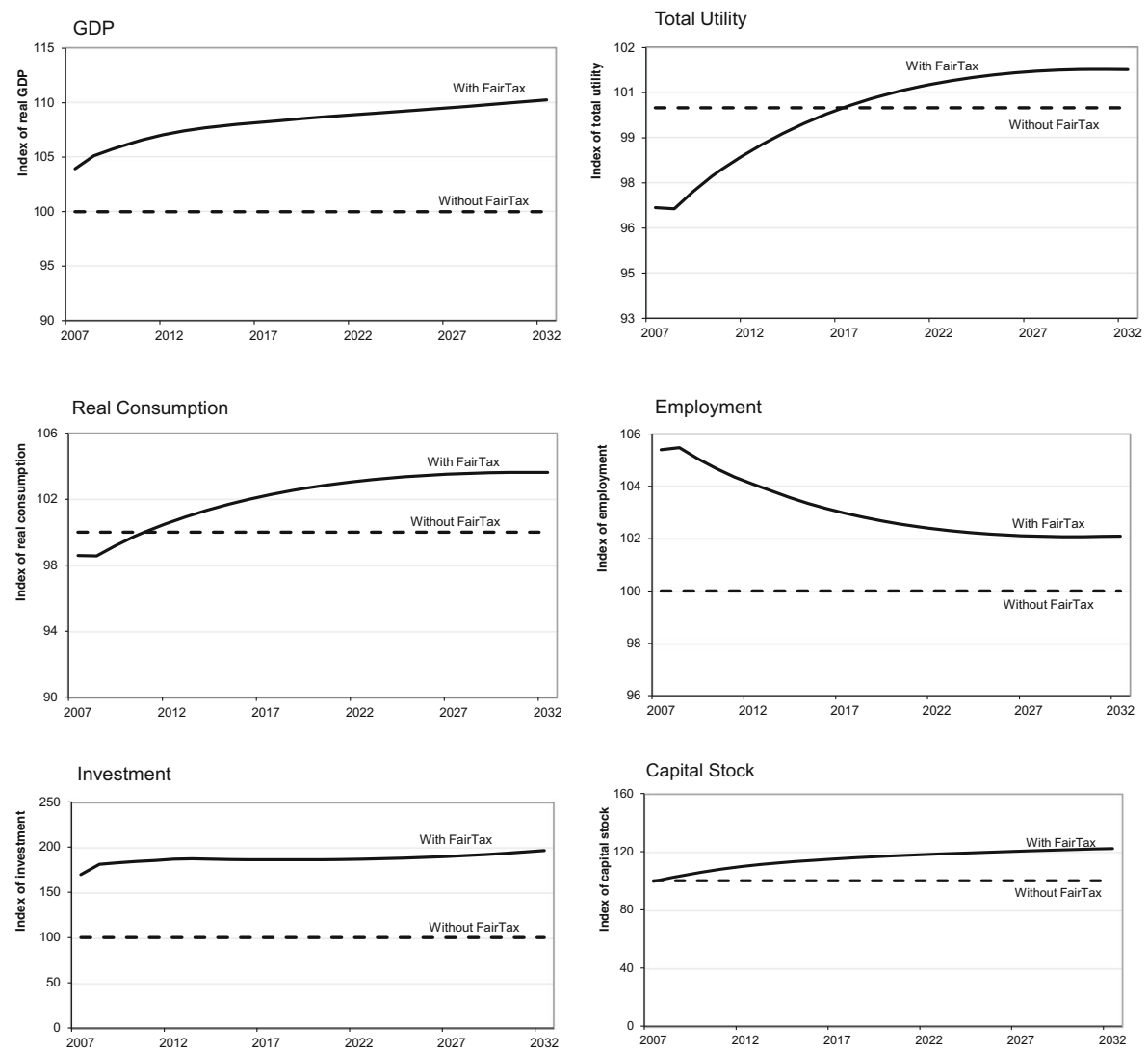

Fig. 3 The effects of the FairTax on GDP, Utility, real consumption, employment, investment, and capital stock, over time. Note: Baseline is set to 100 (horizontal dashed line), and solid line shows relative effect of the FairTax 
Table 3 Index of change in real output, relative to benchmark, by sector

\begin{tabular}{lllllll}
\hline Year & 2007 & 2011 & 2016 & 2021 & 2026 & 2031 \\
Period & 1 & 5 & 10 & 15 & 20 & 25 \\
\hline Industry & & & & & & \\
Agriculture, forestry and fishing & 1.9 & 4.2 & 6.2 & 7.3 & 8.0 & 8.5 \\
Mining & 10.9 & 16.7 & 18.3 & 19.1 & 20.1 & 21.4 \\
Construction & 13.6 & 17.3 & 17.6 & 17.8 & 18.3 & 19.5 \\
Food and tobacco products & -0.1 & 1.5 & 3.4 & 4.4 & 4.9 & 5.2 \\
Textiles and apparel & -0.1 & 1.9 & 3.3 & 4.1 & 4.5 & 4.8 \\
Building materials & 9.2 & 12.2 & 12.7 & 13.0 & 13.5 & 14.5 \\
Paper and publishing & 2.9 & 5.2 & 6.4 & 7.1 & 7.6 & 8.2 \\
Chemicals, petroleum, rubber and plastics & 2.5 & 5.5 & 6.9 & 7.6 & 8.2 & 8.8 \\
Electronics and electronic equipment & 25.8 & 34.0 & 34.7 & 35.0 & 36.3 & 39.1 \\
Motor vehicles and other transportation & 6.1 & 10.9 & 11.7 & 12.1 & 13.0 & 14.6 \\
Primary and fabricated metal & 8.4 & 13.3 & 14.1 & 14.5 & 15.4 & 16.8 \\
Industrial machinery and equipment & 34.0 & 43.7 & 44.5 & 44.8 & 46.3 & 49.5 \\
Business machinery and instruments & 13.3 & 19.2 & 20.2 & 20.7 & 21.6 & 23.2 \\
Other manufacturing & 13.1 & 18.3 & 19.5 & 20.1 & 20.9 & 22.3 \\
Transportation & 1.5 & 3.8 & 5.1 & 5.8 & 6.3 & 6.9 \\
Communications & 4.1 & 7.5 & 9.0 & 9.8 & 10.4 & 11.2 \\
Electricity - gas - sanitary & 1.2 & 4.3 & 6.0 & 6.8 & 7.4 & 7.7 \\
Wholesale trade & 8.0 & 11.8 & 13.0 & 13.6 & 14.3 & 15.3 \\
Retail trade & 0.0 & 1.4 & 2.8 & 3.6 & 4.0 & 4.2 \\
Banking & 1.9 & 4.1 & 5.9 & 6.9 & 7.5 & 7.9 \\
Insurance & 0.7 & 1.0 & 2.9 & 3.9 & 4.5 & 4.7 \\
Real estate & -0.3 & 2.9 & 5.2 & 6.5 & 7.2 & 7.6 \\
Personal and repair services & -10.5 & -9.5 & -8.8 & -8.4 & -8.0 & -7.6 \\
Business services & 5.0 & 8.4 & 9.5 & 10.1 & 10.8 & 11.7 \\
Entertainment and hotel services & -0.9 & 0.5 & 1.8 & 2.4 & 2.8 & 3.0 \\
Health services & -2.5 & -2.5 & -1.3 & -0.3 & 0.3 & 0.5 \\
Other services & -2.4 & -1.3 & -0.1 & 0.5 & 0.8 & 0.9 \\
\hline & & & & & & \\
& & & & & & \\
& & & & & &
\end{tabular}

The essential results from the solutions of the benchmark and FairTax economies are summarized in Table 2, and in Fig. 3, where the graphs are designed so as to begin in the first year of implementation of the FairTax.

The key result is striking: by implementing the FairTax, real output would be $3.9 \%$ higher within a year, $6.8 \%$ greater in year five, and $10.1 \%$ above the benchmark by the end of year 25 . These results slightly higher than those found by Kotlikoff and Jokisch (who use a very different model), and in line with those found by Arduin et al. (2005). The growth would be driven by a surge in savings and investment (Fig. 3, bottom left), which would eventually raise the capital stock by a fifth (Fig. 3, bottom right); there would be a modest rise in employment, and consumption, after falling initially (to allow for higher savings) would eventually rise by about $4 \%$ (Fig. 3, middle panels). Increase 
Table 4 Summary of relative effects of the FairTax on income groups

\begin{tabular}{|c|c|c|c|c|c|c|c|c|c|}
\hline Year & 2007 & 2008 & 2009 & 2010 & 2011 & 2016 & 2021 & 2026 & 2031 \\
\hline Period & 1 & 2 & 3 & 4 & 5 & 10 & 15 & 20 & 25 \\
\hline \multicolumn{10}{|c|}{ \% change in wellbeing ("utility") } \\
\hline$<\$ 10,000$ p.a. & 2.9 & 2.9 & 3.7 & 4.4 & 5.0 & 7.1 & 8.3 & 8.9 & 9.1 \\
\hline$\$ 10,000-25,000$ & -1.3 & -1.3 & -0.6 & -0.1 & 0.4 & 2.2 & 3.2 & 3.8 & 3.9 \\
\hline$\$ 25,000-50,000$ & -3.4 & -3.4 & -2.8 & -2.3 & -1.8 & -0.2 & 0.8 & 1.3 & 1.4 \\
\hline$\$ 50,000-75,000$ & -10.2 & -10.3 & -9.8 & -9.3 & -8.9 & -7.5 & -6.7 & -6.2 & -6.2 \\
\hline$\$ 75,000-100,000$ & -3.2 & -3.3 & -2.7 & -2.3 & -1.8 & -0.3 & 0.6 & 1.0 & 1.1 \\
\hline$\$ 100,000-150,000$ & -4.2 & -4.2 & -3.7 & -3.2 & -2.7 & -1.1 & -0.2 & 0.2 & 0.3 \\
\hline$\$ 150,000$ and up & 13.3 & 13.3 & 13.9 & 14.4 & 14.9 & 16.7 & 17.7 & 18.2 & 18.3 \\
\hline \multicolumn{10}{|c|}{$\%$ change in labor supply } \\
\hline$<\$ 10,000$ p.a. & 1.8 & 1.8 & 1.3 & 0.9 & 0.6 & -0.7 & -1.4 & -1.8 & -1.9 \\
\hline$\$ 10,000-25,000$ & 3.0 & 3.0 & 2.6 & 2.2 & 1.9 & 0.8 & 0.1 & -0.2 & -0.2 \\
\hline$\$ 25,000-50,000$ & 4.4 & 4.5 & 4.1 & 3.7 & 3.5 & 2.4 & 1.8 & 1.5 & 1.5 \\
\hline$\$ 50,000-75,000$ & 9.3 & 9.4 & 9.1 & 8.8 & 8.5 & 7.6 & 7.1 & 6.8 & 6.8 \\
\hline$\$ 75,000-100,000$ & 4.3 & 4.4 & 4.0 & 3.7 & 3.4 & 2.5 & 1.9 & 1.6 & 1.6 \\
\hline$\$ 100,000-150,000$ & 4.7 & 4.7 & 4.4 & 4.1 & 3.9 & 2.9 & 2.4 & 2.1 & 2.1 \\
\hline$\$ 150,000$ and up & -3.4 & -3.3 & -3.6 & -3.9 & -4.2 & -5.1 & -5.7 & -5.9 & -5.9 \\
\hline \multicolumn{10}{|c|}{$\%$ change in net consumption } \\
\hline$<\$ 10,000$ p.a. & 3.6 & 3.6 & 4.4 & 5.1 & 5.7 & 7.9 & 9.1 & 9.8 & 10.0 \\
\hline$\$ 10,000-25,000$ & -0.3 & -0.2 & 0.4 & 1.0 & 1.6 & 3.4 & 4.5 & 5.0 & 5.3 \\
\hline$\$ 25,000-50,000$ & -2.0 & -2.0 & -1.4 & -0.8 & -0.3 & 1.5 & 2.5 & 3.0 & 3.1 \\
\hline$\$ 50,000-75,000$ & -8.7 & -8.7 & -8.1 & -7.6 & -7.2 & -5.6 & -4.7 & -4.3 & -4.2 \\
\hline$\$ 75,000-100,000$ & -1.5 & -1.5 & -0.9 & -0.4 & 0.1 & 1.7 & 2.7 & 3.2 & 3.3 \\
\hline$\$ 100,000-150,000$ & -2.4 & -2.5 & -1.8 & -1.3 & -0.8 & 0.9 & 1.9 & 2.4 & 2.5 \\
\hline$\$ 150,000$ and up & 17.7 & 17.7 & 18.4 & 19.0 & 19.5 & 21.5 & 22.6 & 23.2 & 23.3 \\
\hline
\end{tabular}

in revenue due to higher growth makes the tax system less distortionary in the future as argued in Burger and Zagler (2008).

The disaggregated model also allows one to break down the increase in output by sector when the FairTax is put in place, as shown in Table 3. The investment boom will favor sectors that provide capital goods, including industrial machinery and equipment (where output eventually rises by $46 \%$ ), business machines and equipment ( $+20 \%$ ), electronics $(+36 \%)$, construction $(+13 \%)$, and metals $(+13 \%)$. Over time, as consumption spending rises, there is also increasing demand for most other sectors, including motor vehicles $(+13 \%)$, food and tobacco $(+5 \%)$, textiles and garments $(+5 \%)$, and entertainment and hotels $(+3 \%)$.

The rise in sectoral output is enabled by increases in the capital stock, and in labor inputs. The details of these increases are shown in Appendix Tables 5 and 6. In every sector the capital stock will rise faster than employment - an understandable result given that the FairTax proposal would make capital less expensive relative to labor.

As noted above, household real consumption, and wellbeing ("utility") would fall in the first few years after the introduction of the FairTax, but would then rise above the 

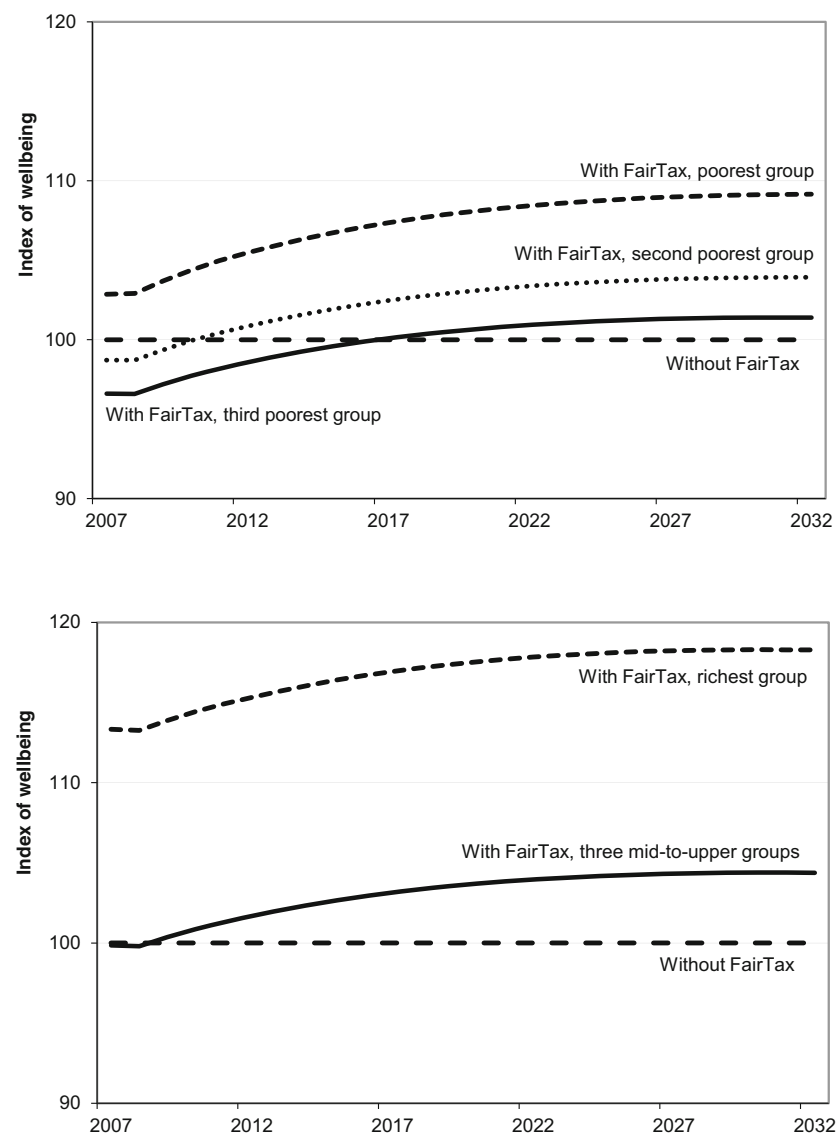

Fig. 4 The effects of the FairTax on Wellbeing ("Utility"), for low- and high-income groups. Note: Baseline is set to 100 (horizontal dashed line), and the other lines show the relative effects of the FairTax

benchmark, so that ultimately the tax change would leave people better off. An interesting question is whether the FairTax would benefit all income groups equally. This is addressed in the numbers presented in Table 4, and the associated graphs in Fig. 4, where the effect of the FairTax on utility, employment, and real consumption is shown, over time, for seven different income groups.

Two groups would benefit unambiguously from the introduction of a FairTax - the poor and the affluent - as the top panel in Table 4 (and the top panel in Fig. 4) makes clear. Very poor households would benefit because the FairTax proposal includes a demogrant, which would provide a cash payment to every household that is set at a level that ensures that anyone spending up to the poverty line would not pay any tax. Currently, poor households do pay some taxes, and by detaxing them, the FairTax would leave them better off. In addition, the growth associated with the FairTax would raise their incomes over time.

At the other end of the spectrum, well-off households would benefit because the FairTax would replace their current relatively high marginal tax rates with a flat tax. Flush with additional purchasing power, this group would take part of its gain in the form of more leisure, thereby reducing its labor supply. 
In between the two extremes, people the other income groups would be less well-off initially, but would see their utility (and real consumption) rise eventually, lifted by rising incomes. The one exception are the households with per capita incomes in the $\$ 50,000$ 75,000 range, who would unambiguously lose. In effect the FairTax would, to some extent, redistribute income from the middle class to the two extremes of the income distribution.

Issues on growth, income inequality and poverty as outlined in Haughthon and Khandker (2009) and particularly in the context of overlapping generation models will be taken up in our forthcoming studies.

\section{Conclusion}

This paper develops a dynamic computable general equilibrium model of the U.S. economy to simulate the principal economic effects of the FairTax on the US economy. The model shows that, by replacing the current income tax with a national sales tax with a demogrant, the proposal would end the double taxation of saving inherent in the existing tax code and, by doing so, raise output, employment, investment and capital stock relative to the benchmark economy.

While these positive effects would be felt almost immediately, the FairTax is very much an investment in the future. Its full benefits would be realized only after the economy achieved a new "steady state," some 20-25 years into implementation. Only by that point will the effects on growth have been fully absorbed into the economy and the wellbeing of most households across most income groups improved. The policy choice, then, is between the status quo, on the one hand, and a new policy that would inflict some short-run pain as the price of a permanently expanded economy.

Acknowledgments We would like to acknowledge the outstanding research assistance provided by Phuong Viet Ngo, and Alfonso Sanchez-Penalver. Earlier version of this paper was presented in the EEFS Conference Thessaloniki Greece in June 2014. We also appreciate an anonymous referee for useful comments on the earlier version of this paper.

\section{Appendix}

Table 5 Index of change in capital stock, relative to benchmark, by sector

\begin{tabular}{lllllll}
\hline Year & 2007 & 2011 & 2016 & 2021 & 2026 & $\begin{array}{l}2031 \\
\text { Period }\end{array}$ \\
\hline Industry & 1 & 5 & 10 & 15 & 20 & 25 \\
$\quad$ Agriculture, forestry and fishing & -0.6 & 4.7 & 10.8 & 14.1 & 16.3 & 17.9 \\
$\quad$ Mining & -1.1 & 19.0 & 24.6 & 27.5 & 29.8 & 32.3 \\
$\quad$ Construction & -0.3 & 24.5 & 30.6 & 33.7 & 36.3 & 39.2 \\
$\quad$ Food and tobacco products & -0.3 & 5.2 & 12.1 & 15.9 & 18.3 & 19.9 \\
$\quad$ Textiles and apparel & -0.3 & 6.8 & 14.7 & 19.1 & 22.0 & 24.2 \\
$\quad$ Building materials & -0.4 & 15.4 & 23.1 & 27.2 & 30.4 & 33.4
\end{tabular}


Table 5 (continued)

\begin{tabular}{lllllll}
\hline Year & 2007 & 2011 & 2016 & 2021 & 2026 & 2031 \\
Period & 1 & 5 & 10 & 15 & 20 & 25 \\
\hline Paper and publishing & -0.6 & 10.0 & 17.4 & 21.4 & 24.2 & 26.5 \\
Chemicals, petroleum, rubber and plastics & -0.4 & 10.2 & 16.2 & 19.4 & 21.7 & 23.6 \\
Electronics and electronic equipment & -2.8 & 37.9 & 47.4 & 52.5 & 57.0 & 62.4 \\
Motor vehicles and other transportation & -1.0 & 17.5 & 26.1 & 30.7 & 34.4 & 38.4 \\
Primary and fabricated metal & -0.5 & 16.6 & 25.0 & 29.5 & 33.1 & 36.9 \\
Industrial machinery and equipment & -1.2 & 48.5 & 57.5 & 62.1 & 66.6 & 72.2 \\
Business machinery and instruments & -0.3 & 24.5 & 31.2 & 34.7 & 37.6 & 40.8 \\
Other manufacturing & -0.3 & 22.4 & 30.0 & 34.0 & 37.2 & 40.5 \\
Transportation & -1.0 & 7.5 & 15.5 & 19.8 & 22.8 & 25.4 \\
Communications & -0.8 & 11.5 & 17.4 & 20.5 & 22.8 & 24.8 \\
Electricity - gas - sanitary & -0.8 & 7.7 & 12.1 & 14.4 & 15.9 & 17.0 \\
Wholesale trade & -0.5 & 15.8 & 24.2 & 28.6 & 32.0 & 35.2 \\
Retail trade & -0.4 & 4.3 & 12.5 & 17.0 & 19.9 & 22.0 \\
Banking & -0.5 & 7.4 & 14.2 & 17.8 & 20.2 & 22.0 \\
Insurance & -0.3 & 0.1 & 10.0 & 15.5 & 19.1 & 21.6 \\
Real estate & -0.1 & 4.5 & 7.8 & 9.6 & 10.6 & 11.3 \\
Personal and repair services & -0.5 & -6.9 & 0.4 & 4.4 & 7.2 & 9.6 \\
Business services & -0.4 & 16.0 & 22.4 & 25.8 & 28.4 & 30.8 \\
Entertainment and hotel services & -0.6 & 6.6 & 13.2 & 16.7 & 19.0 & 20.6 \\
Health services & -0.8 & -6.7 & 0.2 & 8.9 & 15.0 & 19.7 \\
Other services & -1.0 & 4.2 & 11.8 & 15.9 & 18.6 & 20.5 \\
\hline
\end{tabular}

Table 6 Index of change in employment, relative to benchmark, by sector

\begin{tabular}{lllllll}
\hline Year & 2007 & 2011 & 2016 & 2021 & 2026 & 2031 \\
Period & 1 & 5 & 10 & 15 & 20 & 25 \\
\hline Industry & & & & & & \\
$\quad$ Agriculture, forestry and fishing & 7.6 & 4.7 & -0.2 & -2.6 & -4.2 & -5.4 \\
$\quad$ Mining & 29.6 & 13.2 & 9.3 & 7.4 & 6.4 & 6.2 \\
$\quad$ Construction & 19.7 & 14.4 & 12.4 & 11.4 & 11.2 & 11.8 \\
Food and tobacco products & 0.7 & -0.1 & -1.7 & -2.5 & -3.1 & -3.7 \\
$\quad$ Textiles and apparel & 0.9 & 1.3 & 0.5 & 0.2 & -0.1 & -0.3 \\
Building materials & 13.4 & 10.9 & 8.6 & 7.4 & 7.0 & 7.1 \\
$\quad$ Paper and publishing & 4.8 & 3.8 & 2.6 & 2.0 & 1.7 & 1.6 \\
$\quad$ Chemicals, petroleum, rubber and plastics & 6.6 & 3.6 & 1.3 & 0.2 & -0.5 & -0.8 \\
$\quad$ Electronics and electronic equipment & 27.3 & 28.8 & 28.2 & 27.9 & 28.6 & 30.7 \\
$\quad$ Motor vehicles and other transportation & 7.8 & 10.2 & 9.8 & 9.6 & 10.0 & 11.2 \\
$\quad$ Primary and fabricated metal & 11.9 & 12.1 & 10.3 & 9.3 & 9.2 & 9.9 \\
Industrial machinery and equipment & 41.6 & 37.8 & 36.4 & 35.6 & 36.2 & 38.4
\end{tabular}


Table 6 (continued)

\begin{tabular}{lllllll}
\hline Year & 2007 & 2011 & 2016 & 2021 & 2026 & 2031 \\
Period & 1 & 5 & 10 & 15 & 20 & 25 \\
\hline Business machinery and instruments & 20.8 & 15.4 & 13.5 & 12.6 & 12.4 & 13.0 \\
Other manufacturing & 20.3 & 15.7 & 13.7 & 12.6 & 12.3 & 12.8 \\
Transportation & 3.5 & 3.3 & 1.9 & 1.2 & 0.8 & 0.7 \\
Communications & 8.6 & 4.3 & 2.1 & 1.0 & 0.4 & 0.2 \\
Electricity - gas - sanitary & 4.4 & -0.8 & -3.3 & -4.5 & -5.4 & -6.0 \\
Wholesale trade & 11.4 & 10.4 & 9.1 & 8.4 & 8.2 & 8.5 \\
Retail trade & 0.1 & 0.3 & -0.7 & -1.2 & -1.6 & -2.0 \\
Banking & 4.2 & 2.1 & 0.1 & -0.8 & -1.5 & -2.1 \\
Insurance & 1.2 & 1.4 & -0.2 & -1.0 & -1.7 & -2.4 \\
Real estate & -0.1 & -4.9 & -7.6 & -8.9 & -9.9 & -10.7 \\
Personal and repair services & -13.2 & -10.2 & -11.2 & -11.7 & -12.0 & -12.0 \\
Business services & 7.2 & 5.7 & 5.0 & 4.6 & 4.6 & 5.0 \\
Entertainment and hotel services & -1.0 & -1.7 & -2.3 & -2.6 & -2.9 & -3.1 \\
Health services & -2.9 & -1.4 & -1.7 & -2.5 & -3.2 & -4.0 \\
Other services & -2.6 & -2.4 & -2.7 & -2.8 & -3.0 & -3.2 \\
\hline
\end{tabular}

Open Access This article is distributed under the terms of the Creative Commons Attribution 4.0 International License (http://creativecommons.org/licenses/by/4.0/), which permits unrestricted use, distribution, and reproduction in any medium, provided you give appropriate credit to the original author(s) and the source, provide a link to the Creative Commons license, and indicate if changes were made.

\section{References}

Arduin, Laffer, Moore Econometrics (2005) A macroeconomic analysis of the FairTax proposal (preliminary version at http://archive.fairtax.org/u/MacroeconomicAnalysis.pdf)

Arrow JK, Chenery HB, Minhas BS, Solow RM (1961) Capital-labor substitution and economic efficiency. Rev Econ Stat 43(3):225-250

Auerbach AJ, Kotlikoff LJ (1987) Dynamic fiscal policy. Cambridge University Press

Bachman, P, Haughton J, Kotlikoff LJ, Sanchez-Penalver A, Tuerck D (2006) Taxing sales under the FairTax: what rate works? Tax Notes 663-682

Berck P, Golan E, Smith B, Barnhart J, Dabalen A (1996) Dynamic revenue analysis for California. Summer 1996. University of California at Berkeley and California Department of Finance

Bhattarai K (2001) Welfare and distributional impacts of financial liberalization in a developing economy: lessons from forward looking CGE model of Nepal. Working Paper No. 7, Hull Advances in Policy Economics Research Papers

Bhattarai K (2007) Welfare impacts of equal-yield tax reforms in the UK economy. Appl Econ 39(10-12): 1545-1563

Bhattarai K, Whalley J (1999) The role of labour demand elasticities in tax incidence analysis with heterogeneous labour. Empir Econ 24:599-619

Boortz N, Linder J (2005) The FairTax book: saving goodbye to the income tax and the IRS. Regan Books/ Harper Collins, New York 
Brooke A, Kendrick D, Meeraus A, Raman R (1998) GAMS: a user's guide. GAMS Development Corporation, Washington DC

Burger A, Zagler M (2008) US growth and budget consolidation in the 1990s: was there a non-Keynesian effect? IEEP 5:225-235

Council of Economic Advisers (U.S.) (2014) Economic report of the President. US Government Printing Office, Washington DC

Forbes S (2005) Flat tax revolution. Regnery Publishing Company, Washington

U.S. Government Accountability Office (2005) Understanding the tax reform debate: background, criteria, \& questions. GAO-05-1009SP. Washington DC

Hall RE, Rabushka A (1983) Low tax, simple tax, flat tax. McGraw-Hill

Hansen LP, Singleton KJ (1983) Stochastic consumption, risk aversion, and the temporal behavior of asset returns. J Polit Econ 91(2):249-265

Haughthon J, Khandker SR (2009) Handbook on poverty and inequality. World Bank, Washington

Jokisch S, Kotlikoff LJ (2005) Simulating the dynamic macroeconomic and microeconomic effects of the FairTax, NBER Working Paper 11858, Cambridge, MA

Killingsworth M (1983) Labor supply. Cambridge University Press

Kotlikoff LJ (1993) The economic impact of replacing federal income taxes with a sales tax, www.cato.org

Kotlikoff LJ (1998) Two decades of A-K Model, NBER Working Paper, Cambridge MA

Kydland FE, Prescott EC (1982) Time to build and aggregate fluctuations. Econometrica 50:1345-1370

Lau MI, Pahlke A, Rutherford TF (2002) Approximating infinite-horizon models in a complementarity format: a primer in dynamic general equilibrium analysis. J Econ Dyn Control 26(4):577-60

Ogaki M, Reinhart CM (1998a) Intertemporal substitution and durable goods: long-run data. Econ Lett 61:8590

Ogaki M, Reinhart CM (1998b) Measuring intertemporal substitution: the role of durable goods. J Polit Econ 106(5):1078-1098

Piggott J, Whalley J (1985) UK tax policy and applied general equilibrium analysis. Cambridge University Press

Ramsey FP (1928) A mathematical theory of saving. Econ J 38(152):543-559

Reinert KA, Roland-Holst DW (1992) Armington elasticities for United States manufacturing sectors. J Policy Model 14:631-639

Rutherford TF (1995) Applied general equilibrium modeling with MPSGE as a GAMS subsystem: an overview of the modeling framework and syntax. Comput Econ 14:1-46

Shoven JB, Whalley J (1984) Applied general-equilibrium models of taxation and international trade: an introduction and survey. J Econ Lit

Shoven JB, Whalley J (1992) Applying general equilibrium. Cambridge University Press

Tuerck DG, Bachman P, Jacob S (2006) Fiscal federalism: the national FairTax and the states. The Beacon Hill Institute at Suffolk University, Boston

U.S. Congress. Congressional Budget Office (1992) Effects of adopting a value-added tax. U.S. Government Printing Office, 0-318-267 QL 2: 67-74. Washington DC

U.S. Congress. Joint Committee on Taxation (1995) Description and analysis of proposals to replace the federal income tax. 104th Cong., 1st sess 